\title{
Use of paraffin wax embedded bone marrow trephine biopsy specimens as a source of archival DNA
}

\author{
A B Provan, E Hodges, A G Smith, J L Smith
}

\begin{abstract}
Aims: To evaluate the use of DNA extracted from paraffin wax embedded trephine biopsy specimens as a source of archival nucleic acid for Southern hybridisation studies and polymerase chain reaction (PCR) amplification.

Methods: DNA was extracted simultaneously from paraffin wax embedded bone marrow trephine and lymph node biopsy specimens after incubation of tissue sections for one to five days in lysis mix and proteinase $K$ with periodic sampling. DNA from 10 trephine biopsy specimens was subjected to PCR amplification using HLA-DPB primers to determine whether the extracted nucleic acid was of sufficient quality to permit amplification.
\end{abstract}

Results: For most specimens the greatest yield of high molecular weight DNA was seen after five days' incubation. Unlike lymph node material the quality of extracted nucleic acid and the quantity obtained from trephines was insufficient for Southern blot analysis. PCR amplification using HLA-DPB primers yielded positive results in six out of 10 trephine biopsy specimens.

Conclusions: DNA extracted from paraffin wax embedded trephine biopsy specimens is largely degraded and unsuitable for Southern analysis but serves as a useful source of archival nucleic acid for PCR amplification.

Molecular biological techniques have contributed to the diagnosis and classification of human malignancies. In particular, the use of $T$ cell receptor (TCR) and immunoglobulin (Ig) gene probes has aided the classification of human lymphoid malignancies in cases where morphological, cytochemical, and immunophenotypic data are equivocal. Molecular analysis using Southern blotting relies on fresh or frozen biopsy material from which DNA may be extracted. Several groups have reported the use of paraffin wax embedded biopsy material for Southern blot hybridisation and amplification using the polymerase chain reaction (PCR). ${ }^{1-5}$ The advantages of using paraffin wax embedded biopsy specimens include the fact that most pathology departments have archival paraffin blocks spanning a 10-15 year period and these require no specialised storage facilities. To date, most reports on the use of paraffin wax embedded material are based on lymph node, tonsil, skin or other soft tissue biopsy specimens. We attempted to isolate DNA from trephine biopsy specimens from controls and patients with acute lymphoblastic leukaemia, as well as four lymph node biopsy specimens for comparison, to determine whether they serve as a useful archival source of high molecular weight DNA for Southern hybridisation studies and as a source of DNA for PCR amplifications.

\section{Methods}

Paraffin wax embedded trephine and lymph node biopsy specimens were obtained from the Department of Pathology, Southampton General Hospital. The age of the specimens ranged from five years to recent, although for the time course experiment all specimens were taken within the previous year. Ten to $1510 \mu \mathrm{m}$ sections were cut from each paraffin wax block using a microtome and placed in $1.5 \mathrm{ml}$ Eppendorf tubes. To each was added $1 \mathrm{ml}$ warm xylene at $37^{\circ} \mathrm{C}$. Samples were agitated, spun at high speed (13000 rpm) in a microcentrifuge for five minutes, and the supernatant fluid removed. This step was repeated twice. Each sample was then washed twice in $1 \mathrm{ml}$ of xylene:ethanol (1:1), agitated, and spun at high speed for five minutes. A further two washes in ethanol with centrifugation at high speed for five minutes was followed by drying of the pellet at $37^{\circ} \mathrm{C}$ for two hours. To each pellet was added $300 \mu 1$ lysis mixture (per $1500 \mu \mathrm{l}: 450 \mu \mathrm{l}$ proteinase $\mathrm{K}(1 \mathrm{mg} / \mathrm{ml})$, $12.5 \mu \mathrm{l} 1 \mathrm{M}$ DTT, $6 \mu \mathrm{l} 10 \%$ sodium dodecyl sulphate and $1031.5 \mu 1$ lysis buffer containing $0.2 \mathrm{M}$ TRIS- $\mathrm{HCl}, 0.02 \mathrm{M}$ EDTA, $0.2 \mathrm{M}$ $\mathrm{NaCl})$.

Samples were sealed with Parafilm and incubated at $37^{\circ} \mathrm{C}$ for a total of five days with intermittent removal of material at $12,24,48$ hours and five days to determine the optimal time for DNA extraction.

\section{DNA PRECIPITATION}

An equal volume of phenol was added to $75 \mu \mathrm{l}$ aliquots of the digestion mixture and samples mixed by inverting several times before centrifuging at low speed $(6500 \mathrm{rpm})$ in a microcentrifuge. The aqueous layer was removed to a fresh tube and a $100 \mu \mathrm{l}$ backwash performed using distilled water. This step was repeated twice. An equal volume of chloroform (chloroform:isoamyl alcohol 24:1) was added to the samples which were mixed and centrifuged at low speed. The aqueous layer was removed to a fresh tube and a backwash performed. Nucleic 
acid was precipitated by adding one tenth volume $3 \mathrm{M}$ sodium acetate $(\mathrm{pH} \mathrm{5.2)}$ and two volumes of absolute ethanol at $-20^{\circ} \mathrm{C}$. Samples were mixed and stored at $-20^{\circ} \mathrm{C}$ overnight and then spun at $13000 \mathrm{rpm}$ for 10 minutes. The ethanol was aspirated and samples dried at $37^{\circ} \mathrm{C}$ for one hour and redissolved in 10-20 $\mu \mathrm{l}$ distilled water. DNA quality was assessed by electrophoresis of $1 \mu \mathrm{l}$ of sample on a $0.7 \%$ agarose gel and photographed using ultraviolet transillumination.

\section{PCR AMPLIFICATION}

DNA extracted from 10 paraffin wax embedded trephine biopsy specimens was amplified at the following dilutions: undiluted, 1 in 10, 1 in 20,1 in 50,1 in 100 and 1 in 200 dilutions using a Perkin-Elmer DNA Thermal Cycler (Norwalk, Connecticut, USA). Appropriate positive and negative controls were included. The PCR reaction mixture contained the following: $1 \mu \mathrm{l}$ of target DNA, $500 \mathrm{ng}$ of each HLA-DPB primer (DB01 and $\mathrm{DB}^{\circ} 3^{6}$ ), $200 \mu \mathrm{mol}$ each of dNTP and 2.5 Units of Taq DNA polymerase. Sterile water and $10 \times$ PCR buffer were added to a total volume of $100 \mu \mathrm{l}$. Reaction mixtures were overlaid with $50 \mu \mathrm{l}$ mineral oil. After the initial denaturing step $\left(94^{\circ} \mathrm{C}\right.$ for eight minutes) the samples were subjected to 40 cycles of PCR $\left(94^{\circ} \mathrm{C}\right.$ for

Figure 1 Agarose gel
electrophoresis of PCR
amplification products:
$M=$ marker DNA (
Hind III/ $\varphi x 174$ Hinc II
digest); $1-10=$ lanes with
$10 \mu l$ PCR product;
positive amplification seen
in lanes $1,3,4,6,7$ and
$8 ;+/-=$ positive and
negative controls,
respectively.

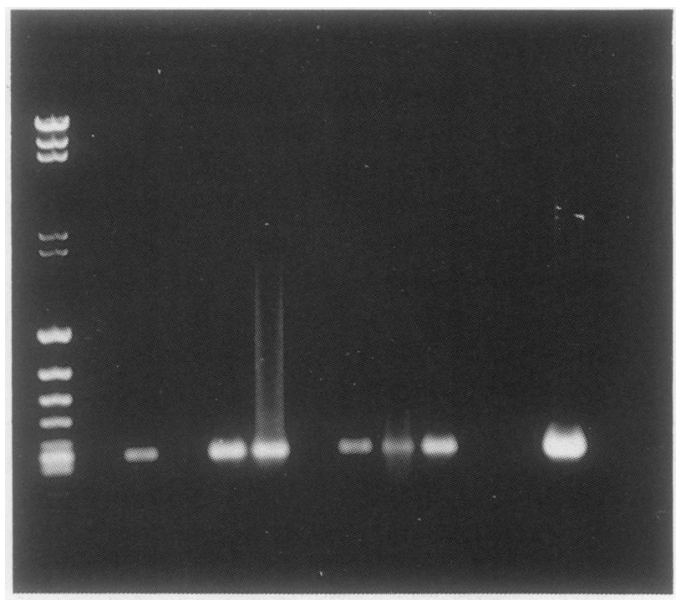

M $12 \begin{array}{lllllllll} & 4 & 5 & 6 & 789 & 10+-\end{array}$

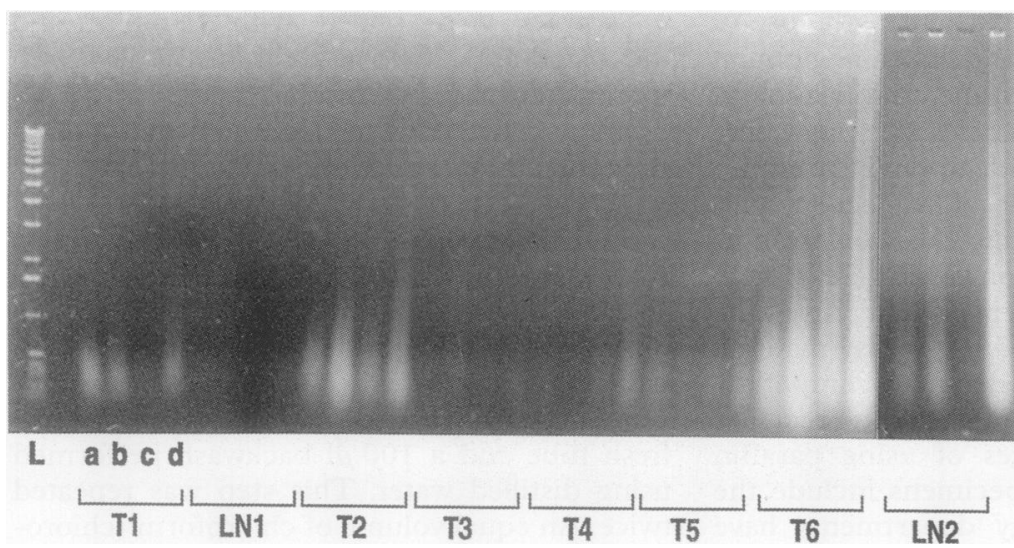

Figure $2 L=1$ kilobase DNA ladder; $T=$ trephone biopsy; $L N=$ lymph node biopsy. All samples had DNA extracted at 12, 24, 48 hours and five days (represented by $a, b, c$ and $d$ from left to right for all samples; only $T 1$ labelled) and run on $0.7 \%$ agarose gel. two minutes, $50^{\circ} \mathrm{C}$ for two minutes, and $72^{\circ} \mathrm{C}$ for two minutes). The last PCR cycle was followed by an additional seven minutes at $72^{\circ} \mathrm{C}$ to ensure that the final extension step was complete. Following amplification, $10 \mu \mathrm{l}$ of each PCR product was run on a $1.5 \%$ agarose gel, stained with ethidium bromide, and photographed using ultraviolet transillumination (fig 1).

\section{Results}

Thirteen trephine and four lymph node biopsy specimens were analysed. For the time course experient six trephines and two lymph nodes were assessed. Figure 2 shows that for most biopsy samples the yield of DNA increases with time, in keeping with previous reports. ${ }^{4}$ After 12 hours, for all specimens, only low molecular weight DNA was recovered; when high molecular weight material was obtained this was only after five days' incubation. We found that three out of four lymph nodes yielded high molecular weight DNA consistent with other reports, ${ }^{7}$ but only one out of 13 trephine biopsy specimens produced significantly high molecular weight DNA. The quality of DNA extracted does not seem to be dependent on age, with some old specimens (1984) yielding high molecular weight DNA, while the DNA from recent specimens was often highly degraded. Some trephines yielded little or no DNA at all as visualised by agarose gel electrophoresis (fig 2, T3-T5).

PCR amplification of DNA extracted from 10 paraffin wax embedded trephine biopsy specimens using HLA-DPB primers DB01 and $\mathrm{DB} 03$ was positive in six out of 10 (fig 1). In most positive cases amplification was seen at high DNA concentrations - undiluted and 1 in 10 dilutions; these samples had been shown earlier to have low DNA concentrations by running $1 \mu \mathrm{l}$ of extracted DNA on a $0.7 \%$ agarose gel. In the four cases which failed to amplify no product was detected in either undiluted or diluted PCR reaction mixtures. These failures may have resulted from inadequate amounts of extracted DNA due to the varying cellularity and DNA content of the trephine biopsy specimens or from the presence of inhibitors.

\section{Discussion}

To date there have been no reports of the use of paraffin wax embedded trephine biopsy specimens as a source of archival DNA. The recovery of DNA from these specimens has been low and the DNA was largely degraded. We feel that processing of the samples is responsible for the lack of intact nucleic acid. Fixation of soft tissue has already been reported to affect the efficiency of the PCR and DNA degradation. ${ }^{5}$ Specimens (soft tissue and trephine) entered into this study were fixed in neutral buffered $10 \%$ formalin for 18-24 hours after biopsy. The soft tissue material was then embedded in wax before sectioning. However, because trephine biopsy specimens contain bone they were decalcified in $5 \%$ formic acid in 
$10 \%$ formalin for 24 hours, followed by neutralisation in $70 \%$ alcohol for six to 12 hours before routine processing through graded alcohols and embedding in paraffin wax. We believe that the decalcification step is responsible for producing the low yield of intact DNA in these specimens.

Paraffin wax embedded trephine biopsy specimens do not lend themselves to extraction of high molecular weight DNA suitable for Southern analysis, but the material obtained is valuable for DNA amplification by PCR. Because most pathology departments store large numbers of paraffin wax embedded biopsy specimens usually spanning several years this technique will allow many cases, perhaps not assessable by other techniques, to be analysed retrospectively. PCR primers are available for immunoglobulin and $T$ cell receptor genes along with many others, and therefore patients with bone marrow pathology in whom no frozen peripheral blood, marrow aspirate, or trephine biopsy specimens are available can, in two thirds of cases, be analysed using DNA extracted from paraffin wax embedded material.
We believe this technique to be of great value in the molecular analysis of many patients with bone marrow pathology, including the detection of minimal residual disease in acute leukaemias and lymphomas.

We are grateful to Dr Bridget Wilkins for technical advice. AP was supported by a grant from Wessex Regional Health Authority.

1 Coates PJ, d'Ardenne AJ, Khan G, Kangro HO, Slavin G. Simplified procedures for applying the polymerase chain reaction to routinely fixed paraffin wax sections. $\mathcal{F}$ Clin Pathol 1991;44:115-8.

2 Dubeau L, Chandler LA, Gralow JR, Nichols PW, Jones PA. Southern blot analysis of DNA extracted from formalinfixed pathology specimens. Cancer Res 1986;46:2964-9.

3 Goelz SE, Hamilton SR, Vogelstein B. Purification of DNA from formaldehyde fixed and paraffin embedded human tissue. Biochem Biophys Res Commun 1985;130:118-26.

4 Jackson DP, Lewis FA, Taylor GR, Boylston AW, Quirke P. Tissue extraction of DNA and RNA and analysis by the polymerase chain reaction. $f$ Clin Pathol 1990;43:499-504

5 Rogers BB, Alpert LC, Hine EAS, Buffone GJ. Analysis of DNA in fresh and fixed tissue by the polymerase chain reaction. Am F Pathol 1990;136:541-8.

6 Howell WM, Sage DA, Haegert DG, Evans PR, Smith JL. PCR-SSO typing for HLA-DPB alleles. Eur $f$ Immunol 1991;18:81-95.

7 Wu AM, Ben-Ezra J, Winberg C, Colombero AM, Rappaport $\mathrm{H}$. Analysis of antigen receptor gene rearrangements in ethanol and formaldehyde-fixed, paraffin embedded specimens. Lab Invest 1990;63:107-14. 